Teaching Assistant George-Marian AEVOAE, PhD

E-mail: aevoae@gmail.com

Associate Professor Roxana DICU, PhD

E-mail: roxana.dicu@uaic.ro

Associate Professor Ioan-Bogdan ROBU, PhD

E-mail: bogdan.robu@feaa.uaic.ro

Associate Professor Daniela MARDIROS, PhD

E-mail: mardirosdanielajob@gmail.com

Department of Accounting, Business Information Systems and Statistics

"Alexandru Ioan Cuza" University of Iasi

Lecturer Florin DOBRE, PhD - Corresponding author

Email: florin.dobre@cig.ase.ro

The Bucharest University of Economic Studies

\title{
UNDERSTANDING THE DYNAMICS OF M\&A MARKET: EMPIRICAL EVIDENCE REGARDING ROMANIAN ACQUISITIONS
}

Abstract. Research question: How do the characteristics of the $M \& A$ transaction and of the target company influence the decision of an acquirer for purchasing a specific amount of capital stake in a Romanian target company? Motivation: The objective of the paper is to identify the influence factors on the stake purchased in Romanian acquisitions, like the method of payment and the premium paid in transaction, controlling for some factors, like the degree of relatedness, the return of the capital employed and the audit status, all specific to the target company. Data: The study is based on a sample of 721 acquisitions, from 2010-2019 period of time. Tools: We use hierarchical linear regression, crosstabulation, ANOVA. Findings: We find that, in Romanian M\&As, premium and the method of payment significantly influence the purchased stake. Contribution: Our findings contribute to the scarce literature on Romanian acquisitions, providing information regarding the influence factors on the purchased stake in acquisitions.

Keywords: acquisitions, Romania, premium, Bucharest Stock Exchange, target companies.

JEL Classification: G11, G34, M21

DOI: 10.24818/18423264/55.2.21.17 
George-Marian Aevoae, Roxana Dicu, Ioan-Bogdan Robu, Daniela Mardiros, Florin Dobre

\section{Introduction}

The acquirers choose a target company based on a variety of reasons, and all of them are related to either synergy, agency theory or hubris theory (Baru and Al-Sabri, 2018; Jensen et al., 2015). After identifying the target, the next step concerns the stake that is to be purchased and which can lead to controlling the target, investing in associate entities or in jointly controlled ones. In this paper, we start from the premise that an acquirer decides to purchase a certain stake as a result of analysing both the transaction and the company that it wants to acquire partially or totally. To study the influences, we propose a linear model, in which the transaction is assessed through the premium paid in transaction (anticipating the synergy expected as a result of transaction) and by the method of payment, chosen to settle the deal. The shareholders of the target company, who are willing to sell their stock, are interested in obtaining a higher premium for a larger stock, fact that is consistent with our results. The characteristics of the acquired company are used as control variables, and they are referring to asset relatedness, the profitability of the target company (calculated using return on capital employed ROCE) (Knauer et al., 2018) and its audit status (unqualified, qualified and unaudited) (Dhaliwal et al., 2018).

Considering the above, from the point of view of the acquirers, several research questions arise:

RQ1: Are the acquirers, located on the Romanian M\&A market, influenced in their decision of purchasing a specific target, by the premiums paid to shareholders of the target company?

RQ2: Does the method of payment (cash or other method) influence the stake purchased in Romanian acquisitions?

RQ3: Are there differences in the behaviour of the acquirers, if we consider the industry acquisitions, compared to services ones?

The paper is structured in three parts. The first part reviews the scientific literature regarding the determinants of mergers and acquisitions and the factors that may influence the acquirer in choosing a specific target, based on characteristics of the transaction and of the acquired company. The second part concerns the research methodology and design. Based on a sample of 721 acquisitions in which the target is a Romanian company, we use crosstabulation, ANOVA and hierarchical regression to analyse the influence of a series of numeric and dummy variables on the stake purchased in Romanian acquisitions. The third part of the paper focuses on the results of our study, regarding the influence of the premium and method of payment on the stake purchased in acquisitions and controlling for target's profitability, the relatedness between the companies involved in transaction and the audit status of the acquired company.

The results will show that the investors are interested in acquiring an amount of stake in Romanian target companies and will pay higher premiums with the increase of stake, in which case they will pay using other payment methods 
Understanding the Dynamics of M\&A Market: Empirical Evidence Regarding Romanian Acquisitions

than cash. In describing the behaviour of acquirers, we notice that they prefer related companies that are not audited, which means that they are interested in horizontal or vertical acquisitions in small companies. Analysing the influence of return on the purchased stake, the results lead us to the size of the target company, and we can affirm that the acquirers are interested in small companies despite their return. When analysing the main economy sectors, we notice different behaviours, namely that the industry sector follows the aforementioned pattern, except the return, while, in the service sector, the preference for alternatives to cash remains, but the acquirers are not that keen regarding the value of premiums.

\section{Literature review and hypotheses development}

Searching for a target in M\&As is a complex process, motivated by a number of factors, which are fundamentally related to the future synergy gains, expected to be obtained as a result of activities. After finding the target company, the next question to be answered is related to the amount to be purchased in the transaction: control, investment in associates or minority interests. The decision is based on predictors like the characteristics of the transaction itself and of the target firms.

A. Factors related to the $M \& A$ transaction: premiums and methods of payment

Following the opinion of Laamanen (2007), premiums represent the amount paid to the shareholders of the target company, over the market value/equity value of the company, and it is a consumption of future synergies for the acquiring companies, next to the integration costs. However, they remain the most notorious form of convincing the aforementioned shareholders to cede their securities, especially in the case of hostile takeovers (Mulherin and Simsir, 2015).

There are authors who fundament their studies on premiums, by presenting the sample, the role of the premium and whether they value acquisitions using preM\&A book value of equity or market value of the target company. Most of the studies base the calculation of the premiums on market value. In calculating the premiums, the timing is also important because a company may choose between original announcement date and the completion date, which may lead to different values for the premium (Mulherin and Simsir, 2014). Independent of the moment of calculation, the premium does not determine negative abnormal returns (Laamanen, 2007), but it may be influenced by other premium paid by a comparable competitor on the same market (Malhotra et al., 2014).

Regarding the size of the premium, powerful CEOs pay lower premiums when they close an acquisition (Fralich and Papadopoulos, 2018), while the premium paid for unlisted targets is lower than the one paid for publicly traded companies, yet the acquirers earning significantly more positive abnormal returns

DOI: 10.24818/18423264/55.2.21.17 
George-Marian Aevoae, Roxana Dicu, Ioan-Bogdan Robu, Daniela Mardiros, Florin Dobre

in the first case (Officer, 2005). On the same topic, due to the fact that the simple difference between the deal value and the corresponding market value of the target company is not sufficient to describe the volume of the premium, all the authors use a relative value, by dividing the difference with the proportionate market value. Seen as a gain for the target's shareholders and as a cost for the acquirers, the premium is very important in assessing the synergy, because a successful acquisition is the one in which the future economic benefits exceed the premium paid in transaction and the integration costs. Davidson III and Cheng (1997) use the premium as a factor of influence for the abnormal returns earned at the date of the transaction, with a positive and significant influence on the return. We consider that the premium negatively affects the equity stake purchased in transaction and, further, we want to explore if the payment method is a significant factor when added to the premium.

Numerous studies demonstrate empirically that choosing a payment method (money, shares or a combination of the two previous alternatives) influences the performance or the wealth of the shareholders, recorded before and after the date of mergers and acquisitions (Faccio and Masulis, 2005). A form of control for obtaining synergies is by including in the contract between the parties of a specification related to a payment method based on performance, either it is the form of shares or in monetary units (Reuer et al., 2004). Myers and Majluf (1984) argued that managers prefer using cash payment if they believe that their acquiring firm is undervalued, while a stock payment is more likely in the opposite case. Thus, they avoid issuing undervalued stock. Moreover, Faccio and Masulis (2005) draw attention to the fact that, when paying with stock, the issuance dilutes dominant shareholder's power. Thus, the choice for a method of payment is related to preserving or not the power of the existing shareholders.

Malmendier et al. (2016) analyses the payment methods from a different perspective, that of the target company value, in the case of unfinished transactions. Based on a study on M\&As that were meant to be closed between 1980 and 2008, the authors concluded that, in the case of transactions involving cash payments, the entities to be acquired were underestimated by $15 \%$ on average after the transaction has failed, compared to the case of transactions where payments were made with securities, in which case there were no significant differences in time regarding the value of the target entity.

Davidson III and Cheng (1997) use the payment with cash as a factor of influence for the abnormal returns registered at the date of the transaction and they assert that this has a positive and significant influence on the return. We consider that the equity stake purchased in transaction is influenced by the method of payment but, what is more important, we want to explore if the payment method is a significant variable when added to the premium. 
Understanding the Dynamics of M\&A Market: Empirical Evidence Regarding Romanian Acquisitions

B. Measurements of a target's characteristics, with influence in $M \& A s$

The term "relatedness" is used in M\&A literature to describe the connectedness, the similarities between the target and the acquirer. The scientific literature offers surprising ways in which this similarity can be seen and used in interpreting and justifying the success/ unsuccess of M\&As.

Chatterjee et al. (1992) start anticipating the synergy through the abnormal return generated by the similarity of resources held by the two companies involved in the transaction. Thus, if a target company is more valuable, in terms of the assets it owns, for a single acquiring company, more than for other competitors, then the winning company will get the benefits associated with the achieved synergies. In contrast, if the target entity is as valuable for many acquiring companies, with no significant differences between them, then all synergy earnings will be transferred to the target company.

A complex image of the relatedness term is proposed by authors Alhenawi and Stilwell (2019), who argue that relatedness plays an important role in how we can achieve value creation in M\&A transactions, and that it is a multi-dimensional concept. The authors base their assertion on the fact that, when used as a variable, the relatedness offers multiple results, according to the studies published. Thus, its content is multi-faceted, and it can include operational similarities (specific mostly to horizontal transactions), vertical supply chain integration, familiarity with local market, focus, geographical proximity, technology etc. given the complexity of the term, they are of the opinion that the influence of relatedness in the process of M\&A evaluation is not "fully" analysed.

Anyway, in most cases, the measurement for relatedness is the NACE Rev. 2 code (for Europe) or any other industry classification codes which lead to a possible correlation between the core activities, hence the assets of the companies involved in M\&As. Following this commonly used approach (Lee et al., 2018), we adopt the degree of relatedness based on NACE Rev. 2 codes for the acquirer and the target company, as they are reported for describing the companies involved in acquisitions. Thus, acquisitions between companies with a common activity at the two-digit level (or greater) are classified as related acquisitions, although the method could be considered as biased and with serious limitations, especially in the case of economies of scope and dynamic complementarities.

Many empirical studies on acquisitions and their transaction prices include a profitability measure as a proxy for the target's expected cash flow as an explanatory variable. Target profitability is typically proxied by returns, and as predicted by theory, the coefficient on profitability is generally significant and positive (Hagendorff et al., 2012). But profitability is a factor that can influence the acquisition from both sides, not only target's, because acquiring firms with better performance may have more resources to involve in acquisitions (Shi et al., 2017).

In proving an unqualified opinion on the target company's financial information provided to users, the trust in the statutory audit is analysed by Xie et

DOI: 10.24818/18423264/55.2.21.17 
George-Marian Aevoae, Roxana Dicu, Ioan-Bogdan Robu, Daniela Mardiros, Florin Dobre

al. (2013), who assert that companies which are audited by Big $\mathrm{N}$ auditors are more probable to being acquired in a M\&A transaction. The authors' assertion is related to the risk for an investor to be misinformed, the reputation of the Big $\mathrm{N}$ auditors giving a supplementary assurance and insurance regarding the quality of the information provided in the financial reports of the target companies. The assertion is also sustained by the study of Lim and Lee (2015), who found a direction relationship between the quality of the financial information provided by the target company and the success of the M\&A, measured in the announcement returns recorded by the acquirers. In the case of the Romanian target companies, only the ones that are listed on Bucharest Stock Exchange and the one considered to be of public interest certify their financial reports. Thus, there is a possibility that the Romanian target companies are not audited, so this factor can be used to describe them.

\section{Hypotheses development}

For a long time, market for corporate control in the countries of Central and Eastern Europe was dominated by privatization, companies searching for investors. Unlike other countries in this area, Romania has had a more fluctuating, rather controversial evolution. In the last 30 years, the process of privatization of Romanian companies followed mainly three directions: the purchase of securities by employees (EBO); mass privatization; the sale, in most cases, of large packages of securities to external investors. However, the state remained the owner of some strategic companies, partially or entirely, despite the announcements regarding the acceleration of the privatization process. In the years following the mass privatization program, more than $10 \%$ of the five thousand privatized companies listed on the stock market were targets for takeovers.

During years, most of the Romanian companies were privatised, so the acquisitions of a controlling interest have become fewer and fewer. As a result, on the Romanian M\&A market, the purchased stake varies from minority acquisitions to acquisitions of $100 \%$ of the target' shares, hence the discussion on the factors that may influence the decision of the acquirers.

Considering the influence factors of the stake purchased in acquisitions, hypotheses proposed to be tested and validated are as follows:

$\mathrm{H}_{1}$ : The stake purchased in Romanian M\&As is significantly influenced by the characteristics of the transactions. The influence is analysed for the whole sample of M\&A transactions.

The specificities of the manufacturing (industry) companies, compared to the ones in services, are discussed by Lian et al. (2019) in the case of cross-border M\&As, by Belderbos et al. (2010), when analysing innovative performance, and by Rozen-Bakher (2018), when comparing the M\&A success in horizontal, vertical and conglomerate M\&As. Thus, we have the following two hypotheses: 
Understanding the Dynamics of M\&A Market: Empirical Evidence Regarding Romanian Acquisitions

$\mathrm{H}_{2}$ : The stake purchased in Romanian industry M\&As is significantly influenced by the characteristics of the transactions. According to EU, sections AG from NACE Rev. 2 are associated to industry.

$\mathrm{H}_{3}$ : The stake purchased in Romanian services M\&As is significantly influenced by the characteristics of the transactions. According to EU, sections $\mathrm{H}-$ $\mathrm{U}$ from NACE Rev. 2 are associated to services.

The last two hypotheses are to be tested and validated for industry acquisitions and services acquisitions, considering the NACE Rev. 2 code reported by the target company for the year of the acquisition.

These hypotheses will be tested and validated using the statistical software SPSS 25.0.

\section{Research methodology and design}

The study aims at analysing the influence of a number of characteristics on the investment made by the acquirers in the equity of the target companies, considering the example of Romanian M\&A activity, namely acquisitions.

Target population and analysed sample. To test and to validate the proposed research hypotheses, the study analyses the empirical data related to 721 acquisitions with known deal value, for the 2010 - 2019 period of time, in which at least one Romanian company is involved. The target companies are those that presented available financial information for our independent variables. The information was taken from Zephyr and Orbis databases.

Out of these, 633 transactions are industry acquisitions, and 88 transactions are services acquisitions. The data regarding the NACE main section for the target company are collected from Zephyr database, for the 2010-2019 period of time.

To reach the proposed research hypotheses, we use linear regression, crosstabulation, ANOVA and event study methodology.

Models and methods used for data analysis. To test and validate the hypotheses, we use hierarchical linear regression (HLR), because it is a way to show if independent variables explain a statistically significant amount of variance in the purchased stake, after accounting for all other variables.

In order to explore the influence of payment methods (cash or other) and of the proportional premium on the stake purchased in Romanian acquisitions, we regress the dependent variable against a dummy variable and one measuring the relative premium paid in transaction, reported to the market capitalization of the target company, starting from the model proposed by Davidson III and Cheng (1997). The authors measure, in their paper, the relative relationship between the aforementioned variables and the abnormal returns in acquisitions, but we replaced the dependent variable with the purchased stake, because of the results reported by Hagendorff et al. (2012), who assert that deals involving a change in control do not result in higher premiums, compared to deals involving the purchase of minority

DOI: 10.24818/18423264/55.2.21.17 
George-Marian Aevoae, Roxana Dicu, Ioan-Bogdan Robu, Daniela Mardiros, Florin Dobre

stakes (negative relationship). Later, we control for variables link to the target company: asset relatedness, return on capital employed (ROCE) and audit status.

The regression model is presented in eq. 1 , as follows:

$\% \_$Stake $=\beta_{0}+\beta_{1} \cdot$ Cash $+\beta_{2} \cdot$ Premium $+\sum_{j=3}^{n} \beta_{j} C V_{j}+\varepsilon_{i}$

where $C V_{j}$ are the control variables added to the model

We have three hierarchical models, presented in eq. 2-4.

$\% \_$Stake $=\beta_{0}+\beta_{1} \cdot$ Cash $+\beta_{2} \cdot$ Premium $+\beta_{3} \cdot \operatorname{ROCE}+\varepsilon_{\mathrm{i}}$

$\% \_$Stake $=\beta_{0}+\beta_{1} \cdot$ Cash $+\beta_{2} \cdot$ Premium $+\beta_{3} \cdot \operatorname{ROCE}+\beta_{4} \cdot$

Unrelated_acq $+\beta_{5} \cdot$ Undisclosed_acq $+\varepsilon_{i}$

$\%$ Stake $=\beta_{0}+\beta_{1} \cdot$ Cash $+\beta_{2} \cdot$ Premium $+\beta_{3} \cdot$ ROCE $+\beta_{4}$.

Unrelated_acq $+\beta_{5} \cdot$ Undisclosed_acq $+\beta_{6} \cdot$ Qualified $+\beta_{7}$.

Unqualified $+\varepsilon_{\mathrm{i}}$

The last three models are used to test the proposed hypotheses (for the whole sample, and separately for industry acquisitions and service acquisitions).

Dependent variable. This variable (\%_Stake) represents the stake purchased by the acquirer in the target company. Thus, this variable is a percentage between $0.018 \%$ (shares in jointly controlled entities) and $93.603 \%$ (acquisition of a controlling interest). The stakes that were purchased in Romanian acquisitions were taken from the Zephyr database, for the 2010-2019 period of time.

Independent variables.

Method of payment (Cash) is referring to the methods used by the acquirers to pay for the securities of the target. This is a dummy variable which takes value 1 when the deal is financed by cash only and 0 when other methods of payment are used (i.e. even if we have a mix between cash and these methods).

The acquisition premium (Premium) is paid by the acquiring company to target's shareholders and it is calculated as the difference between the deal value (the transaction price) and the pre-acquisition market capitalization divided by the pre-acquisition market capitalization of the target.

Control variables. Return on capital employed (ROCE) is a performance ratio which describes the target company, and it is calculated for the year before the acquisition took place. Because it reflects the efficiency with which the capital of the target was used, we consider it a reliable measure of performance for the acquired company.

The study includes three types of acquisitions as control variables to explore which of them influences most the stake purchased on Romanian market. These variables were based on the NACE Rev.2 main code of the acquirer and the target before the M\&A took place.

Related/unrelated/undisclosed acquisitions. These variables (Related_acq, Unrelated_acq, and Undisclosed_acq, respectively) were defined as a dummy

DOI: $10.24818 / 18423264 / 55.2 .21 .17$ 
Understanding the Dynamics of M\&A Market: Empirical Evidence Regarding Romanian Acquisitions

variable, where 1 represents a specific type of acquisition and 0 represents other. Related acquisitions were measured in terms of the similarity of the industries of the acquirer and the target, based on the three-digit level of the NACE Rev.2 classification. Unelated acquisitions were measured in terms of the lack of similarity of the industries of the acquirer and the target, based on the three-digit level of the NACE Rev.2 classification. Undisclosed acquisitions were determined based on the fact that the acquirer was not presented in Zephyr Database, because he/it decided to remain unknown.

The audit status (Audit_status) is a dummy variable which controls for the influence of the audit status of the target company on the stake purchased in Romanian acquisitions. This variable takes three forms: qualified (1 for qualified and 0 for others), unqualified ( 1 for unqualified and 0 for other) and unaudited ( 1 for unaudited and 0 for others).

Analysis of variance or ANOVA is an analysis of the statistical variation of a quantitative variable, $\mathrm{Y}$, relative to one or more explanatory, categorical $\mathrm{X}$ variables with $\mathrm{k}$ categories. From the target population $\mathrm{k}$ independent samples are randomly extracted based on $X$ variable structure (Jaba, 2002). The statistical hypotheses are:

$\mathrm{H}_{0}: \mu_{1}=\mu_{2}=\ldots=\mu_{\mathrm{k}}$

$\mathrm{H}_{1}: \mu_{\mathrm{i}} \neq \mu_{\mathrm{j}}, \forall \mathrm{i} \neq \mathrm{j}, \mathrm{i}, \mathrm{j}=\overline{1, k}$

In our study, we consider the analysis of the means of equity stake, considering the audit status and the relatedness.

\section{Results and discussions}

In our sample of 721 acquisitions that involved a Romanian company as target, 661 transactions $(91.68 \%)$ were paid only with cash while $60(8.32 \%)$ were settled using either a mixture of cash and other forms of payment or they excluded cash. From a number of 721 transactions only 661 used cash as method of payment, from which 588 represent the industry sector and 73 the service, and 60 other methods of payment. When analysing for relatedness a total of 12 transaction were related, 99 unrelated and 610 undisclosed. Analysing the audit status, we noticed that 582 transactions with the status unqualified were paid in, 2010-2019 period of time, with cash and 42 with other methods of payment (i.e. securities, a mix of cash and stock).

We use ANOVA on the data recorded at the sample level (721 transactions), and we find significant differences between the average stake that a bidder acquires in the target company considering the audit status of the target company (Qualified, Unqualified and Unaudited). The analysis is significant ( $\mathrm{F}=$ 18.473 , sig. $=0.000)$ with a mean square between groups of $2,172.746$ and within groups of 117.620. Testing for homogeneity of variances, it reveals a sig. value of 0.000 , which shows the fact that the groups have significantly different variances.

DOI: 10.24818/18423264/55.2.21.17 
George-Marian Aevoae, Roxana Dicu, Ioan-Bogdan Robu, Daniela Mardiros, Florin Dobre

As consequence, for testing the equality of means between groups, we used the Welch and Brown-Forsythe test.

Table 1. ANOVA - mean stake and the audit status of the targets

\begin{tabular}{lrrrrr}
\hline Factors & \multirow{2}{*}{ N } & \multirow{2}{*}{ Mean } & \multicolumn{2}{l}{$\begin{array}{l}\text { Std. } \\
\text { Deviation }\end{array}$} & \multicolumn{2}{l}{$\begin{array}{l}\text { Robust Test for Equality of Means } \\
\text { Wrown-Forsythe }\end{array}$} \\
\hline Qualified & 7 & 5.231000 & 7.0186395 & F-ratio = 15.799; & F-ratio = 71.421; \\
Unqualified & 624 & 3.842279 & 10.4833896 & df2 = 15.799; sig. & df2 $=71.421 ;$ sig. \\
Unaudited & 90 & 11.273911 & 13.2763116 & $=0.001$ & $=0.000$ \\
Total & $\mathbf{7 2 1}$ & $\mathbf{4 . 7 8 3 4 2 7}$ & $\mathbf{1 1 . 1 0 5 3 5 7 0}$ & & \\
\hline
\end{tabular}

Source: Own projection using SPSS 25.0

In Table 1 we notice that the mean steak of the target group with the qualified opinion ( 7 transactions) is approximatively $5,23 \%$, the mean stake purchased in target companies that received an unqualified opinion (624 transactions) is $3,84 \%$ and the mean for unaudited targets (90 transactions) is $11,27 \%$. The Welch and Brown-Forsythe tests are used to test for a significant difference across the means when the equal variances test results in the rejection of the null hypothesis $\left(\mathrm{H}_{0}: \mu_{\text {unqualified }}=\mu_{\text {qualified }}=\mu_{\text {unaudited }}\right)$. In our case, the two tests are significant for both ANOVAs ( $<<0.01)$. From the results, we can assert that the acquirers prefer to purchase larger stakes in unaudited companies, which apply local GAAP. The explanation may be the lack of regulation and the fact that reporting requirements for unaudited companies are at a lower level than the companies that are audited.

Table 2. LSD test - mean stake and the audit status of the targets

\begin{tabular}{|l|l|r|l|r|}
\hline Audit status (I) & Audit status (J) & Mean difference (I-J) & Std. error & Sig. \\
\hline \multirow{2}{*}{ Qualified } & Unqualified & 1.3887213 & 4.1220614 & .736 \\
\cline { 2 - 5 } & Unaudited & -6.0429111 & 4.2555597 & .156 \\
\hline \multirow{2}{*}{ Unqualified } & Qualified & -1.3887213 & 4.1220614 & .736 \\
\cline { 2 - 5 } & Unaudited & $\mathbf{- 7 . 4 3 1 6 3 2 4} *^{* * *}$ & 1.2228597 & .000 \\
\cline { 2 - 6 } & Qualified & 6.0429111 & 4.2555597 & .156 \\
\cline { 2 - 5 } & Unqualified & $\mathbf{7 . 4 3 1 6 3 2 4 * * *}$ & 1.2228597 & .000 \\
\hline \multirow{2}{*}{ ***. The mean difference is significant at the 0.05 level. } \\
\hline
\end{tabular}

Source: Own projection using SPSS 25.0

LSD post hoc analysis is performed to investigate which groups differed significantly from others on their mean variable scores. Table 2 presents the post hoc analysis for target's audit status. Considering the audit status to group the target companies (Qualified, Unqualified and Unaudited), post hoc analysis revealed significant differences only for mean stakes purchased in target companies that had, for the financial statements published for the year prior to the acquisitions, an unqualified audit opinion, compared to the mean stake purchased 
Understanding the Dynamics of M\&A Market: Empirical Evidence Regarding Romanian Acquisitions

in unaudited target companies (see Table 2) $(p<0.01)$. The other comparisons reveal no significant differences.

Table 3 shows the ANOVA for our sample, grouped according to the degree of relatedness between the core activities of the companies involved.

Table 3 The ANOVA and descriptive statistics of the sample, based on relatedness

\begin{tabular}{lllll}
\hline Variables & Related & Unrelated & Undisclosed & Total \\
\hline Observations & \multicolumn{1}{c}{12} & \multicolumn{1}{c}{99} & \multicolumn{1}{c}{610} & $\mathbf{7 2 1}$ \\
Mean & 15.197500 & 9.643960 & 3.789720 & $\mathbf{4 . 7 8 3 4 2 7}$ \\
Std Deviation & 18.7145072 & 10.5844004 & 10.6998732 & $\mathbf{1 1 . 1 0 5 3 5 7 0}$ \\
Minimum & .2420 & .0180 & .0190 & $\mathbf{0 1 8 0}$ \\
Maximum & 67.0100 & 57.1050 & 93.6030 & $\mathbf{9 3 . 6 0 3 0}$ \\
F & 10.878 & 22.644 & 33.141 & $\mathbf{3 3 . 1 4 1}$ \\
Sig. & 0.001 & 0.000 & 0.000 & $\mathbf{0 . 0 0 0}$ \\
Welch \& & $\mathrm{F}=3.821 ; \mathrm{df}=$ & $\mathrm{F}=23.938 ; \mathrm{df}=$ & $\mathrm{F}=29.146 ; \mathrm{df}$ & \\
Brown- & $11.126 ;$ sig. $=$ & $133.948 ;$ sig. $=$ & $=145.166 ;$ sig. & \\
Forsythe & .076 & .000 & $=.000$ & \\
\hline Souce: & & &
\end{tabular}

Source: Author's own processing using SPSS 25.0

According to the data in Table 3, the mean stake for the related acquisitions (12 transactions) presents the highest value $(15,20 \%)$, followed by the mean stake for unrelated transactions (99 transactions), with the value of $9,64 \%$ and for undisclosed transactions $(3,79 \%)$. Thus, in Romanian acquisitions, the horizontal and vertical concentrations are preferred, compared to conglomerate ones, in terms of the purchased stake. The lowest stakes (the majority of them being minority stakes) are purchased by undisclosed buyers, which are mainly private investors. In Romania, the changes in ownership are stipulated in Companies Law no. 31/1990, republished in 2004, with further amendments, they require an additional act to the company's bylaws which later changes the Registry of Shareholders, but there is no requirement about the information being made public. Also, we performed a t-test to compare the means stake purchased in the transactions paid with cash, compared to the one purchased using other means of payment. For the 661 transactions that were paid with cash, the mean stake is $4,06 \%$, while the mean stake for the 60 transactions paid with other instruments (securities) is $12,77 \%$. The difference is significant at $5 \%$ level $(\mathrm{t}=4.725$, sig. $=$ $0.000)$.

The estimation of the parameters for the proposed regression models are presented in Table 4. The table also includes the parameters for industry acquisitions and services acquisitions, considering the NACE Rev.2 main code of the target company.

DOI: 10.24818/18423264/55.2.21.17 
Economic Computation and Economic Cybernetics Studies and Research, Issue 2/2021; Vol. 55

Table 4. Parameters estimates for the regression models

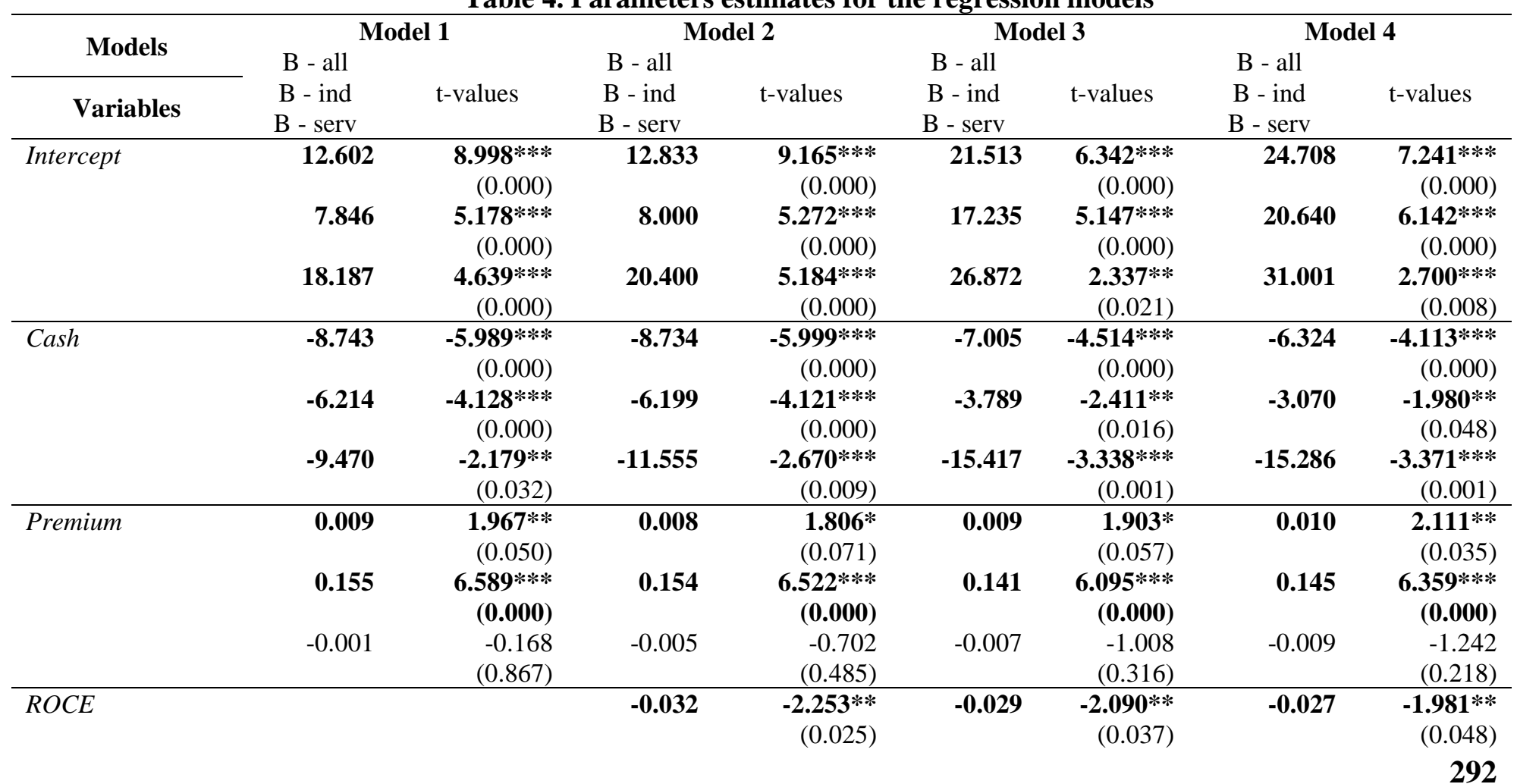

DOI: 10.24818/18423264/55.2.21.17 
Understanding the Dynamics of M\&A Market: Empirical Evidence Regarding Romanian Acquisitions

\begin{tabular}{|c|c|c|c|c|c|c|c|c|}
\hline \multirow{3}{*}{$\begin{array}{c}\text { Models } \\
\text { Variables }\end{array}$} & \multirow{3}{*}{$\begin{array}{l}\mathrm{B} \text { - all } \\
\mathrm{B}-\text { ind } \\
\mathrm{B}-\text { serv }\end{array}$} & Model 1 & \multicolumn{2}{|c|}{$\begin{array}{ll}\text { Model } 2 \\
\end{array}$} & \multicolumn{2}{|c|}{ Model 3} & \multicolumn{2}{|c|}{ Model 4} \\
\hline & & \multirow[b]{2}{*}{$\mathrm{t}$-values } & \multirow{2}{*}{$\begin{array}{l}\mathrm{B} \text { - all } \\
\mathrm{B}-\text { ind } \\
\mathrm{B}-\text { serv }\end{array}$} & \multirow[b]{2}{*}{$\mathrm{t}$-values } & \multirow{2}{*}{$\begin{array}{l}\mathrm{B} \text { - all } \\
\mathrm{B} \text { - ind } \\
\mathrm{B} \text { - serv }\end{array}$} & \multirow[b]{2}{*}{$\mathrm{t}$-values } & \multirow{2}{*}{$\begin{array}{l}\text { B - all } \\
\text { B - ind } \\
\text { B - serv }\end{array}$} & \multirow[b]{2}{*}{ t-values } \\
\hline & & & & & & & & \\
\hline & & & -0.019 & $\begin{array}{r}-1.455 \\
(0.146)\end{array}$ & -0.016 & $\begin{array}{r}-1.269 \\
(0.205)\end{array}$ & -0.014 & $\begin{array}{r}-1.127 \\
(0.260)\end{array}$ \\
\hline & & & -0.283 & $\begin{array}{r}-\mathbf{2 . 3 4 4 * * *} \\
(0.021) \\
\end{array}$ & -0.311 & $\begin{array}{r}-\mathbf{2 . 5 8 2} * * * \\
(0.012) \\
\end{array}$ & -0.424 & $\begin{array}{r}\mathbf{- 3 . 2 8 0} \\
(0.002) \\
\end{array}$ \\
\hline \multirow[t]{3}{*}{ Unrelated $^{l}$} & & & & & -7.287 & $\begin{array}{r}-\mathbf{2 . 2 1 9} * * * \\
(0.027)\end{array}$ & -6.824 & $\begin{array}{r}-\mathbf{2 . 1 0 6 * * *} \\
(0.036)\end{array}$ \\
\hline & & & & & -6.944 & $\begin{array}{r}-\mathbf{2 . 1 8 0} * * * \\
(0.030)\end{array}$ & -6.607 & $\begin{array}{r}-\mathbf{2 . 1 1 1 * * *} \\
(0.035)\end{array}$ \\
\hline & & & & & -9.704 & $\begin{array}{r}-0.876 \\
(0.383)\end{array}$ & -9.812 & $\begin{array}{r}-0.901 \\
(0.370)\end{array}$ \\
\hline \multirow[t]{3}{*}{ Undisclosed $^{l}$} & & & & & -10.982 & $\begin{array}{r}\mathbf{- 3 . 5 3 1} * * * * \\
(0.000)\end{array}$ & -9.674 & $\begin{array}{r}\mathbf{- 3 . 1 4 1} * * * * * \\
(0.002)\end{array}$ \\
\hline & & & & & -12.172 & $\begin{array}{r}-\mathbf{4 . 0 3 7} * * * * \\
(0000)\end{array}$ & -10.959 & $\begin{array}{r}-\mathbf{3 . 6 8 7} * * * * \\
(0000)\end{array}$ \\
\hline & & & & & -1.024 & $\begin{array}{r}-0.097 \\
(0.923) \\
\end{array}$ & 0.838 & $\begin{array}{r}0.080 \\
(0.936)\end{array}$ \\
\hline \multirow[t]{3}{*}{ Qualified $^{2}$} & & & & & & & -3.903 & $\begin{array}{r}-0.939 \\
(0.348)\end{array}$ \\
\hline & & & & & & & -4.863 & $\begin{array}{r}-0.732 \\
(0.465)\end{array}$ \\
\hline & & & & & & & -18.018 & $-2.221 * *$ \\
\hline
\end{tabular}

DOI: 10.24818/18423264/55.2.21.17 
George-Marian Aevoae, Roxana Dicu, Ioan-Bogdan Robu, Daniela Mardiros, Florin Dobre

\begin{tabular}{|c|c|c|c|c|c|}
\hline \multirow{2}{*}{ Models } & \multirow{2}{*}{ Model 1} & Model 2 & Model 3 & \multicolumn{2}{|c|}{ Model 4} \\
\hline & & B - all & B - all & B - all & \\
\hline \multirow[t]{2}{*}{ Variables } & $\begin{array}{l}\text { B - ind } \\
\text { B - serv }\end{array}$ & $\begin{array}{l}\text { B - ind } \\
\text { B - serv }\end{array}$ & $\begin{array}{l}\text { B - ind } \\
\text { B - serv }\end{array}$ & $\begin{array}{l}\text { B - ind } \\
\text { B - serv }\end{array}$ & $\mathrm{t}$-values \\
\hline & & & & & $(0.029)$ \\
\hline \multirow[t]{3}{*}{ Unqualified $^{2}$} & & & & -5.756 & $\begin{array}{r}-\mathbf{4 . 7 2 1} * * * * \\
(0.000)\end{array}$ \\
\hline & & & & -5.893 & $\begin{array}{r}-4.956 * * * \\
(0.000)\end{array}$ \\
\hline & & & & -5.896 & $\begin{array}{r}-1.482 \\
(0.142)\end{array}$ \\
\hline \multirow[t]{3}{*}{ Observations } & \multicolumn{5}{|c|}{721 acquisitions } \\
\hline & \multicolumn{5}{|c|}{633 industry acquisitions } \\
\hline & \multicolumn{5}{|c|}{88 services acquisitions } \\
\hline$R^{2}$ & 0.052 & 0.059 & 0.085 & & 0.112 \\
\hline$F$ & $\begin{array}{r}\mathrm{F}=19.745 ; \text { df }(2,718) \\
\text { sig. }=0.000\end{array}$ & $\begin{array}{r}\mathrm{F}=14.930 ; \text { df }(3,717) ; \\
\text { sig. }=0.000\end{array}$ & $\begin{array}{r}\mathrm{F}=13.205 ; \text { df }(5,715) \\
\text { sig. }=0.000\end{array}$ & $\mathrm{~F}=12.9$ & $\begin{array}{l}; \text { df }(7,713) ; \\
\text { sig. }=0.000\end{array}$ \\
\hline$R^{2}$ & 0.098 & 0.101 & 0.145 & & 0.178 \\
\hline$F$ & $\begin{array}{r}\mathrm{F}=34.242 ; \text { df }(2,630) ; \\
\text { sig. }=0.000\end{array}$ & $\begin{array}{r}\mathrm{F}=23.574 ; \text { df }(3,629) ; \\
\text { sig. }=0.000\end{array}$ & $\begin{array}{r}\mathrm{F}=21.302 ; \text { df }(5,627) ; \\
\text { sig. }=0.000\end{array}$ & $\mathrm{~F}=19.2$ & $\begin{array}{r}\text {;f }(7,625) ; \\
\text { sig. }=0.000\end{array}$ \\
\hline$R^{2}$ & 0.055 & 0.113 & 0.162 & & 0.213 \\
\hline$F$ & $\begin{array}{r}\mathrm{F}=2.488 ; \mathrm{df}(2,85) ; \\
\text { sig. }=0.089\end{array}$ & $\begin{array}{r}\mathrm{F}=3.578 ; \text { df }(3,84) ; \\
\text { sig. }=0.017\end{array}$ & $\begin{array}{r}\mathrm{F}=3.169 ; \mathrm{df}(5,82) ; \\
\text { sig. }=0.011\end{array}$ & $\mathrm{~F}=3$. & $\begin{array}{r}9 ; \mathrm{df}(7,80) ; \\
\text { sig. }=0.006\end{array}$ \\
\hline
\end{tabular}


The first model predicts how much of the variance of the dependent variable is justified by the chosen dependent variables (method of payment and the premium). The regression model is significant $(\mathrm{F}(2,718)=19.745 ; \mathrm{p}<0.001)$ but explains a small percentage of the variance in the dependent variable $\left(\mathrm{R}^{2}=.052\right)$. The predictors account for $5,2 \%$ of the variance of the purchased stake. Related to the significance of the variables, both of them have a significant influence on the DV, when all the sample is considered for analysis. Given the fact that the model is tested for industry acquisitions and services acquisitions, we will notice some differences. Overall, the premium has a significant positive influence on the stake purchased in transaction (sig. $=0.050, \mathrm{t}=1.967$ for all acquisitions, sig. $=0.000, \mathrm{t}$ $=6.589$ for industry acquisitions), which means the premium increases with the purchased stake, both in all the sample and the industry acquisitions, which is consistent with other studies (Moeller et al., 2004). Using Pearson correlation between premium and size of the company, we noticed they are negatively correlated $(r=-0.072$, sig. $=0.054)$. In the case when the acquirers are purchasing stake in target companies that operate in services, the premium in not significant. Paying with cash in Romanian acquisitions has a negative and significant influence on the purchase stake (sig. $=0.000, \mathrm{t}=-5.989$, sig. $=0.000, \mathrm{t}=-4.128$ and sig. $=$ $0.032, \mathrm{t}=-2.179$, respectively). We can conclude that, in Romanian acquisitions, the payment using securities or others means of payment lead to a higher stake.

The second model explore if the return of the target company is a significant variable when added to the previous model. With a $\mathrm{F}(3.717)=14.930$ and a sig. $=0.000$, the model is significant for the whole sample, but also for industry acquisitions $(\mathrm{F}(3,629)=23.574$, sig. $=0.000)$ and services acquisitions $(\mathrm{F}(3,84)=3.578$, sig. $=0.017)$. The increase of $\mathrm{R}^{2}$ is very small, which means that the return on capital employed only explains $0.7 \%$ of the variance of the purchased stake in all acquisitions, $0.3 \%$ in industry acquisitions, but explains $5.8 \%$ of the variance in services acquisitions. The result shows that EBIT, which is one of the main accounting values leading to ROCE, is not sufficient in describing the influence of this return on the purchased stake, given the fact that industry target companies have long-term assets that are depreciated. The influence of ROCE on the dependent variable is negative. Searching for a meaning of the negative sign, we run a Pearson Correlation test between the size of the company (as $\ln$ (total_assets) for the target), ROCE and stake. The results showed that the size is positively correlated with ROCE $(r=0.104$, sig. $=0.005)$ and negative with stake $(r$ $=-0.500$, sig. $=0.000$ ). We consider that acquirers are targeting small companies, despite their reported return.

The relatedness between the companies is a control variable added to the third model and it has a significant and negative influence at a 5\% level in the case of the whole sample and in industry acquisitions. Thus, the acquirers purchase larger stakes in related companies, compared to unrelated $(\mathrm{sig} .=0.027, \mathrm{t}=-2.219$, and sig. $=0.030, \mathrm{t}=-2.180$ respectively) and undisclosed (sig. $=0.0000, \mathrm{t}=-3.531$, and sig. $=0.002, \mathrm{t}=-3.141$ respectively). This is consistent with the ANOVA

DOI: 10.24818/18423264/55.2.21.17 
George-Marian Aevoae, Roxana Dicu, Ioan-Bogdan Robu, Daniela Mardiros, Florin Dobre

(average stake in related acquisitions is $15.20 \%$, compared to $9.64 \%$ in unrelated and $3.79 \%$ in undisclosed transactions). The degree of relatedness is not significant in services acquisitions.

When adding the audit status to the final model, the investment pattern is getting clearer. The unaudited companies are preferred for purchasing larger stakes, compared to those that received unqualified opinion from an independent auditor, in our whole sample and in industry acquisitions (sig. $=0.000, \mathrm{t}=-4.721$, and sig. $=0.000, t=-4.956$ respectively). In services acquisitions, the acquirers prefer to purchase larger stakes in unaudited companies, instead of those that received qualified opinion, which is a normal behaviour for an investor.

\section{Conclusions}

Thirty years have passed since the fall of communism, and the Romanian market economy still finds itself in a struggle were the lack of regulation, the constant change of the fiscal laws, the slow rhythm of infrastructure development, and lack of investment in public sector seem to characterize the public policy. As a consequence, companies find themselves in a position from which growth strategies may help them achieve synergy, seen both as an achievement and as a way out (through cost savings and/or revenue increase). In this context, we draw an investment pattern of the acquirers on Romanian acquisition market, based on the characteristics of the target company.

Our study focuses on a sample of 721 acquisitions which has as main point of interest the Romanian target companies seen as a whole and then separated into industry sector (633 transactions) and services (88 transactions). Investors are interested in acquiring an amount of stake in Romanian target companies and will pay higher premiums with the increase of stake. They also prefer other methods of payment instead of cash, or, if they prefer cash, they will purchase a smaller stake. Following a behavioural pattern, we notice that acquirers prefer related companies that are not audited, which means that they are interested in horizontal or vertical acquisitions in small companies. The latter are not burdened by the regulations required for the companies that are listed on Bucharest Stock Exchange or large companies that have the obligation to be audited. Analysing the influence of return on the purchased stake, the results lead us to the size of the target company, and we can affirm that the acquirers are interested in small companies despite their return.

The industry sector follows a similar pattern, except the return which does not influence the behaviour of the investors searching for a target company in industry. The acquisitions in the service sector, on the other hand, have a different one. In terms of method of payment, the preference for alternatives to cash remains and, in this case, it seems that investors are not that keen regarding the value of premiums. When searching for a related company we noticed that the industry sector, acquirers prefer companies that are unaudited and find less likely the option to choose those which are audited.

DOI: 10.24818/18423264/55.2.21.17 
Understanding the Dynamics of M\&A Market: Empirical Evidence Regarding

Romanian Acquisitions

Given the fact that Romania has no more than twenty-two years since the reopening of the BSE and three decades since the implementation of free market, it still has much to learn in terms of acquisitions, in order to follow the normal trend and for Romanian companies to reach the expected synergies.

ACKNOWLEDGEMENTS: This work was supported by a grant of the Romanian Ministry of Education and Research, CNCS - UEFISCDI, project number PN-III-P1-1.1-TE-2019-1642, within PNCDI III.

\section{REFERENCES}

[1] Alhenawi, Y., Stilwell, M. (2019), Toward a Complete Definition of Relatedness in Merger and Acquisition Transactions. Review of Quantitative Finance and Accounting, 53, 351-396;

[2] Baru, P.A., Al-Sabri, H.M. (2018), Mergers and Acquisitions in Malaysia:

Do They Increase Shareholder Wealth?. Journal of Advanced Research in Business and Management Studies, 10(1): 40-51;

[3] Belderbos, R., Bolat, I., Jacob, J., Lokshin, B. (2010), International Technology Alliances, Technology-based M\&As, and the Innovative Performance of $\boldsymbol{E U}$ and non-EU firms, available online at http://www.lem.sssup.it/WPLem/documents/papers EMAEE/jacob.pdf, accessed 1 November 2020;

[4] Chatterjee, S., Lubatkin, M., Schweiger, D., Weber, Y. (1992), Cultural Differences and Shareholder Value in Related Mergers: Linking Equity and Human Capital. Strategic Management Journal, 13(5): 319-334;

[5] Davidson III, W.N., Cheng, L. (1997), Target Firm Returns: Does the Form of Payment Affect Abnormal Returns?. Journal of Business Finance \& Accounting, 24(3)\&(4): 465-479;

[6] Dhaliwal, D., Lamoreaux, P., Litov, L., Neyland, J. (2016), Shared Auditors in Mergers and Acquisitions. Journal of Accounting and Economics, 61(1): 49-76;

[7] Faccio, M., Masulis, R. (2005), The Choice of Payment Method in European Mergers and Acquisitions. The Journal of Finance, 60(3): 1345-1388;

[8] Fralich, R., Papadopoulos, A. (2018), The Financial Crisis, Acquisition Premiums and the Moderating Effect of CEO Power. Long Range Planning, 51(2): 204-218;

[9] Hagendorff, J., Hernando, I., Nieto, M. J., \& Wall, L. D. (2012), What Do Premiums Paid for Bank M\&As reflect? The Case of the European Union. Journal of Banking \& Finance, 36(3): 749-759;

DOI: $10.24818 / 18423264 / 55.2 .21 .17$ 
George-Marian Aevoae, Roxana Dicu, Ioan-Bogdan Robu, Daniela Mardiros, Florin Dobre

[10] Jaba, E. (2002), Statistica, $3^{\text {rd }}$ ed. Economica Publishing; București;

[11] Jensen, I., Sanning, L.W., Stuart, N.V. (2015), Do Hubris and the

Information Environment Explain the Effect of Acquirers' Size on Their Gains

from Acquisitions?. Journal of Economics and Finance, 39(2): 211-234;

[12] Knauer, T., Silge, L., Sommer, F. (2018), The Shareholder Value Effects of Using Value-based Performance Measures: Evidence from Acquisitions and Divestments. Management Accounting Research, 41, 43-61;

[13] Laamanen, T. (2007), On the Role of Acquisition Premium in Acquisition Research. Strategic Management Journal, 28(13): 1359-1369;

[14] Lee, K. H., Mauer, D. C., Xu, E. Q. (2018), Human Capital Relatedness and Mergers and Acquisitions. Journal of Financial Economics, 129(1): 111-135; [15] Lim, J., Lee, J. (2015), Financial Reporting Quality of Target Companies and Acquirer Returns: Evidence from Korea. International journal of accounting \& information management, 23(1): 16-41;

[16] Malhotra, S., Zhu, P. \& Reus, T. H. (2014), Anchoring on the Acquisition Premium Decisions of others. Strategic Management Journal, 36(12): 1866-1876; [17] Malmendier, U., Opp, M., Saidi, F. (2016), Target Revaluation after Failed Takeover Attempts: Cash versus Stock. Journal of Financial Economics, 119(1): 92-106;

[18] Moeller, S. B., Schlingemann, F. P., Stulz, R. M. (2004), Firm Size and the Gains from Acquisitions. Journal of Financial Economics, 73(2): 201-228;

[19] Mulherin, H., Simsir, S.A. (2014), Measuring Deal Premiums in Takeovers. Financial Management, 44(1): 1-14;

[20] Myers, S. C., Majluf, N. S. (1984), Corporate Financing and Investment Decisions when Firms Have Information that Investors Do not Have. Journal of Financial Economics, 13(2): 187-221;

[21] Officer, M.S. (2005), Premiums in Acquisitions of Unlisted Targets, available at SSRN: https://ssrn.com/abstract $=685556$ or http://dx.doi.org/10.2139/ssrn.685556;

[22] Reuer, J., Shenkar, O., Ragozzino, R. (2004), Mitigating Risk in International Mergers and Acquisitions: The Role of Contingent Payouts. Journal of International Business Studies, 35, 19-32;

[23] Rozen-Bakher, Z. (2018), Comparison of Merger and Acquisition (M\&A) Success in Horizontal, Vertical and Conglomerate M\&As: Industry Sector Vs. Services Sector. The Service Industries Journal, 38(7-8): 492-518.

[24] Shi, W., Zhang, Y., Hoskisson, R. E. (2017), Ripple Effects of CEO Awards: Investigating the Acquisition Activities of Superstar CEOS' Competitors. Strategic Management Journal, 38(10): 2080-2102;

[25] Xie, Z., Lin, R., Mi, J., Li, N. (2019), Improving Enterprises' Cross-Border M\&A Sustainability in the Globalization Age-Research on Acquisition and Application of the Foreign Experience. Sustainability, 11(11): 3180. 